\title{
Aspek Pengukuran Kinerja Perusahaan
}

\section{Nama : Adra Elviona Regina}

\section{Email : adraelvionaa@gmail.com}

Performa suatu perusahaan memiliki banyak pengukuran yang akan bergantung pada tujuan perusahaan itu sendiri. Kinerja suatu perusahaan ini salah satunya dapat diukur dengan mempertimbangkan nilai tertinggi dan nilai terendah dari suatu perusahaan, serta menggunakan pengukuran rata - rata keuntungan dari perusahaan tersebut (Moaniba, Su, \& Lee, 2020). Selain itu perusahaan juga mengukur kinerja nya melalui tiga ukuran kinerja keuangan yaitu Tobin's Q , ROA , dan ROE serta diikuti oleh tiga proxy integritas CEO (Pham \& Tran, 2020). Dalam pengukuran kinerja perusahaan yang menggunakan Tobin's Q ini juga menyesuaikan dengan harga saham yang potensial bagi sang pemimpin perusahaan dan tidak sekedar melihat dari sisi investor saja (Feng, Patel, \& Sivakumar, 2020). Tidak hanya itu, ada juga perusahaan yang mengukur kinerja dengan menggunakan peran dari Corporate Social Responsibility (CSR) yang digunakan untuk menguji kerangka kinerja yang terdiri dari tujuh hipotesis (Hunjra, Boubaker, Arunachalam, \& Mehmood, 2020). Kinerja suatu perusahaan juga dapat diukur melalui rasio keuangan perusahaan tersebut agar pemilik perusahan dapat menilai baik buruknya suatu keputusan berhubungan dengan keuangan yang diambil (Suoniemi, Meyer-Waarden, Munzel, Zablah, \& Straub, 2020).

Tertulis pada jurnal Pratono 2016 dijelaskan mengenai penelitian tentang kinerja perusahaan. Kinerja perusahaan ini dapat diukur melalui data kuantitatif atau dalam bentuk suatu informasi yang mengukur kinerja perusahaan melalui orientasi strategi yang dimiliki oleh perusahannya dan juga diikuti dengan perkembangan teknologinya (Pratono, Strategic orientation and information technological turbulence: Contingency perspective in SMEs, 2016). Sedangkan yang tertulis pada jurnal Pratono 2019 ini kinerja perusahaan dapat diukur menggunakan data kualitatif yaitu diukur dari keuntungan strategis yang diperoleh dari para pesaing perusahaan. Selain itu kinerja perusahaan juga diukur dengan cara meninjau efek yang mungkin terjadi akibat adanya perubahan lingkung bisnis yang dialami oleh pelanggan serta mencari keputusan atau 
kesepakatan untuk merespon ketentuan perubahan harga yang dibuat oleh para pesaing (Pratono, Darmasetiawan, Yudiarso, \& Jeong, 2019)

\section{Bibliography}

Feng, C., Patel, P. C., \& Sivakumar, K. (2020). Chief global officers, geographical sales dispersion, and firm performance. Journal of Business Research, 121, 58 - 72.

Hunjra, A. I., Boubaker, S., Arunachalam, M., \& Mehmood, A. (2020). How does CSR mediate the relationship between culture, religiosity and firm performance? Finance Research Letters. doi:https://doi.org/10.1016/j.frl.2020.101587

Moaniba, I. M., Su, H.-N., \& Lee, P.-C. (2020). Geographic distance between co-inventors and firm performance: The moderating roles of interfirm and cross-country collaborations. Technological Forecasting \& Social Change, 157, 2.

Pham, H. S., \& Tran, H. T. (2020). CSR disclosure and firm performance: The mediating role of corporate reputation and moderating role of CEO integrity. Journal of Business Research, 120, 127 - 136.

Pratono, A. H. (2016). Strategic orientation and information technological turbulence: Contingency perspective in SMEs. Business Process Management Journal, 22 (2), 368 - 382.

Pratono, A. H., Darmasetiawan, N. K., Yudiarso, A., \& Jeong, B. G. (2019). "Achieving sustainable competitive advantage through green entrepreneurial orientation and market orientation: The role of inter-organizational learning". The Bottom Line, 31(1), 2 - 15.

Suoniemi, S., Meyer-Waarden, L., Munzel, A., Zablah, A. R., \& Straub, D. (2020). Big Data and Firm Performance: The Roles of Market-Directed Capabilities and Business Strategy. Information \& Management, 57(7), 35 - 38. 